\author{
Urszula OlejNik \\ Uniwersytet Marii Curie-Skłodowskiej w Lublinie \\ ORCID - 0000-0003-2391-123X
}

\title{
STYLE POCZUCIA HUMORU NAUCZYCIELI WEDŁUG MODELU RODA MARTINA. BADANIA PILOTAŻOWE
}

\begin{abstract}
Streszczenie: Humor w pedagogice jest zagadnieniem nowym i coraz częściej podejmowanym przez badaczy przedmiotu. W artykule zaprezentowane są wyniki badań empirycznych, których celem było poznanie stylów humoru nauczycieli. Badaniami kwestionariuszowymi z wykorzystaniem Kwestionariusza Stylów Humoru objęto grupę 41 nauczycieli szkół podstawowych i przedszkoli. Okazało się, że stylami humoru najczęściej prezentowanymi przez nauczycieli są adaptacyjne jego formy, zdecydowanie rzadziej - nieadaptacyjne. Zauważono także spadek poziomu wszystkich stylów humoru wraz z wiekiem i stażem pracy nauczycieli.
\end{abstract}

Słowa kluczowe: humor, humor w edukacji, style humoru, style humoru nauczycieli

\section{WPROWADZENIE}

Humorem zajmowali się najwięksi myśliciele ludzkości, m.in. Platon, Arystoteles, Epiklet, Kartezjusz, Pascal, Kant, Hegel. Każdy z nich dostrzegając jego zalety, ale także wady, stwierdzał, że jest on nieodzowną częścią życia człowieka (Carrol 2018). Obecnie zagadnieniami związanymi z humorem zajmuje się humorologia i skupia ona badaczy różnych dziedzin nauki, m.in. socjologów, lingwistów, genetyków, kognitywistów, pedagogów i psychologów. Poczucie humoru było rozpatrywane dotychczas jako stan, cecha, zdolność, światopogląd, utrwalony wzór zachowania, strategia radzenia sobie, inter- $\mathrm{i}$ intrapersonalny styl funkcjonowania jednostki (Tomczuk-Wasilewska 2010). 


\section{HUMOR I JEGO FUNKCJE}

Według słownika języka polskiego humor to „zdolność dostrzegania zabawnych stron życia”, „chwilowy stan usposobienia, zwłaszcza: pogodny nastrój”. Z kolei Rod A. Martin (2003) stwierdza, że humor to „uniwersalna aktywność ludzka, której każdy człowiek doświadcza wielokrotnie w ciągu dnia, niezależnie od społecznego kontekstu" (s. 35). Według Zygmunta Freuda (1905) jest to jeden z najbardziej skutecznych mechanizmów obronnych, a Maslow i Allport uważali, że osoby potrafiące żartować $\mathrm{z}$ siebie w sposób nieagresywny i które jednocześnie akceptują swoją osobę posiadają zdrową i dojrzałą osobowość (Maslow 1954; Allport 1961; za: Bulzak, Adamczyk, Kordek 2016). Wielu autorów jest zgodnych co do tego, że dzięki humorowi człowiek może wyjść z wielu sytuacji trudnych, niezręcznych $\mathrm{z}$ „twarzą", tj. ochraniając wewnętrzny obraz siebie przed negatywną opinią czy oceną społeczną (Radomska 2002; Bulzak, Adamczyk, Kordek 2016).

Anna Rusek (2012) dokonując przeglądu literatury przedmiotu dotyczącej wielowymiarowości humoru, stwierdziła, że według badaczy zajmujących się tym zagadnieniem może on pełnić następujące funkcję:

1. Wychowawczą - związaną z przekazywaniem norm regulujących życie społeczne, tradycji rodzinnych i narodowych; jest także mechanizmem umożliwiającym porozumienie międzypokoleniowe (Pirecki 2000; Dudzikowa 1996; za: Rusek 2012).

2. Edukacyjną - dzięki której poznajemy znaczenie humoru w procesie edukacyjnym. Okazuje się, że humor wprowadza atmosferę sprzyjającą zapamiętywaniu materiału, zwiększa motywację uczniów do nauki, jest niezastąpionym przerywnikiem podczas opanowywania dużych i trudnych partii materiału, a podczas sytuacji egzaminacyjnych zmniejsza u uczniów poziom lęku (Tomczuk-Wasilewska 2009).

3. Intelektualno-twórczą - gdzie humor ujmowany jest jako forma rozwijającej zabawy i gry poznawczej, w której podkreślana jest w szczególności funkcja poznawcza humoru, ściśle połączona z zaskoczeniem, zdziwieniem, gdy dzięki humorowi właśnie znane dotąd zjawisko stawiane jest w nowym świetle (Tomczuk-Wasilewska 2009). Twórcza funkcja humoru jest związana $\mathrm{z}$ umiejętnością przekształcania napotykanych trudności w sposób akceptowalny przez jednostkę i z umiejętnościami myślenia dywergencyjnego czy redefiniowania. Według Turnera (2003; za: Rusek 2012) ta funkcja humoru jest niezbędna ludziom dla odpoczynku, uczenia się ról społecznych, rozwoju jaźni i budowy koncepcji własnego Ja.

4. Światopoglądową - w ten sposób rozumiana funkcja humoru wiąże się z prezentowaniem przez jednostkę postawy wobec życia i otaczającej rze- 
czywistości, którą cechuje humor i życzliwość wobec innych osób. Przejawia się tolerowaniem i akceptowaniem pomyłek i niedoskonałości innych osób, a także przyjmowanie niespodziewanych zdarzeń losowych jako niezbędnej części rzeczywistości ludzkiej, prowadzącej do refleksyjnego patrzenia na sens egzystencji człowieka (Ruch 2004; za: Tomczuk-Wasilewska 2009).

5. Wspierającą zdrowie fizyczne - poczucie humoru i śmiech pozytywnie wpływają na układ immunologiczny człowieka, podnoszą poziom endorfin, dotleniają organizm i pozytywnie wpływają na pracę serca. Wywołują pozytywne emocje wpływające na kondycje organizmu, a także są stosowane jako mechanizm obronny chroniący przed skutkami przeżywanego stresu (za: Rusek 2012).

Maria Kmita (2013) stwierdza, że w obecnych badaniach nad humorem można wyraźnie dostrzec dwa kierunki: pierwszy traktuje humor jako narzędzie, bądź umiejętność wykorzystywaną do osiągania celów; drugi podkreśla znaczenie humoru podczas budowania relacji z drugim człowiekiem, atmosfery i samopoczucia. Niezależnie od sposobu definiowania i klasyfikowania humoru należy stwierdzić, że jest on integralną i nieodzowną składową funkcjonowania wszystkich instytucji, w tym zakładów pracy, szkół itp. Prowadzone badania pokazują, że humor wykorzystywany jest w miejscach pracy jako narzędzie do poprawy relacji między ludzkich, komunikacji, wprowadzania innowacji i zwiększaniu uprawnień pracowników, a także pomaga konstruktywnie rozwiązywać konflikty, poprawia solidarność zawodową w miejscu pracy (za: Karłyk-Ćwik 2016).

\section{ROLA HUMORU W EDUKACJI}

Badania nad humorem w edukacji pokazują, że jest on często wykorzystywaną strategią $\mathrm{w}$ pracy $\mathrm{z}$ dziećmi i młodzieżą $\mathrm{i}$ jednocześnie stanowi jedną $\mathrm{z}$ najbardziej pożądanych przez uczniów cech osobowości. Zdaniem Marty Musiatewicz (2014) humor i jego umiejętne używanie w relacjach nauczyciel - uczeń buduje i umacnia wzajemne porozumienie. Poczucie humoru nauczyciela jest też sposobem na przełamanie dystansu, który jest wpisany w asymetryczną relacje nauczyciel - uczeń. Musiatewicz (2014) przeprowadziła badania pośród młodzieży szkół ponadpodstawowych, które wykazały, że uczniowie mający do wyboru udział w zajęciach dwóch kompetentnych pedagogów, z których jeden prowadzi zajęcia w sposób „oschły”, a drugi z poczuciem humoru, wybiorą zajęcia u drugiego nauczyciela. Uczniowie potwierdzili, że u nauczyciela posiadającego poczucie humoru lekcje są nie tylko ciekawsze, ale także sprzyjają zrozumieniu materiału, wprowadzają uczniów w dobry nastrój i budują atmosferę korzystną 
dla uczenia się. Do podobnych wniosków doszli Moshe Machlev i Nancy Karlin (2016), którzy na podstawie przeprowadzonych badań własnych stwierdzili, że dobrany w odpowiedni sposób humor na lekcji koreluje pozytywnie z postrzeganym uczeniem się. Uczniowie są bardziej zmotywowani i chętni do nauki, kiedy nauczyciel używa różnych jego rodzajów podczas prowadzenia lekcji. $\mathrm{Na}$ podkreślenie zasługuje także fakt, że ukierunkowanie humoru na treści charakterystyczne, ważne dla danego przedmiotu pozwalają na ich podkreślenie i lepsze zapamiętanie.

Humor wpływa pozytywnie na powstawanie więzi społecznych poprzez mechanizmy identyfikacji i selekcji, tj. osoby żartujące razem i posiadające podobne poczucie humoru odczuwają silniejszą przynależność do grupy. W psychologii wyróżniane są cztery funkcje humoru w kontekście komunikacji interpersonalnej:

- identyfikująca - pomaga osobie żartującej w ujawnieniu treści, które bez użycia humoru pozostałyby w ukryciu;

- klaryfikująca - umożliwia lepsze zapamiętanie tych wiadomości, które zostały wyrażone za pomocą ciętej riposty;

- egzekwująca - oznacza przekazywanie zasad wychowania w formie żartobliwej, a nie moralizatorskiej;

- różnicująca - dzięki zastosowaniu humoru można przekazać treści niepopularne w danej grupie, czy nawet kontrowersyjne.

Musiatewicz (2014) zauważa, że nauczyciel może z powodzeniem wykorzystywać te wszystkie funkcje humoru w pracy z uczniami bez obawy, że narazi się na śmieszność bądź utratę autorytetu. Cała sztuka polega na żonglowaniu humorem w sposób spontaniczny i naturalny, tak aby jednocześnie usprawnić proces komunikacji, wychowania czy też nauczania - uczenia się. Taki rodzaj humoru w pracy nauczyciela Stanisław Gajda nazywa „wtrąconym komizmem” (s. 15).

Zastosowanie humoru w pracy nauczyciela jest efektywnym sposobem na poradzenie sobie nie tylko w procesie nauczania - uczenia się, ale przede wszystkim w pracy wychowawczej, współpracy ze środowiskiem zewnętrznym, a także rodzicami ucznia. Zarówno polscy, jak i zagraniczni badacze procesów edukacyjnych i wszystkich elementów z nimi związanych są zgodni co do tego, że poczucie humoru w instytucjach oświatowych wpływa na jakość więzi emocjonalnych pomiędzy nauczycielami, wychowankami i ich rodzicami: zmniejsza dystans, rodzi zaufanie, poczucie porozumienia i akceptacji. Umiejętne posługiwanie się humorem wpływa pozytywnie na częstotliwość i jakość nawiązywanych w szkole kontaktów, a także może służyć efektywnemu wywieraniu wpływu na grupę, rozwiązywaniu konfliktów i rozładowywaniu napięć (Musiatewicz 2014; Karłyk-Ćwik 2016; Machlev, Karlin 2016). Dodatkowo poczucie humoru chroni nauczycieli przed wypaleniem zawodowym, wyczerpaniem psychicznym i poczuciem braku 
osiągnięć. Autorzy Bulzak, Adamczyk i Kordek (2016) stwierdzają, że nauczyciele obdarzeni humorem rzadziej odczuwają brak osiągnięć, mają także bardziej pozytywny obraz własnej osoby w porównaniu z osobami o niższym jego poziomie. Co więcej autorzy stwierdzają, że sytuacje stresowe są częściej postrzegane przez osoby z wyższym poziomem poczucia humoru w kategoriach wyzwań, a sam humor przybiera formę efektywnej strategii $\mathrm{w}$ radzeniu sobie $\mathrm{w}$ sytuacji stresowej. Humor poza swoistą funkcją „buforu” chroniącego nauczycieli przed sytuacjami trudnymi sprzyja także rozwijaniu ich kompetencji komunikacyjnych, co z punktu widzenia specyfiki wykonywanego zawodu jest kompetencją kluczową, bez której ciężko jest sobie wyobrazić tzw. nauczyciela z powołania. Wnioski badaczy zajmujących się poczuciem humoru nauczycieli w kontekście wypalenia zawodowego są jednoznaczne: humor nauczycieli może obniżać stres związany z pracą i zapobiegać zjawisku wypalenia zawodowego. Jest to niezwykle ważne w szczególności w przypadku nauczycieli, gdzie poziom wypalenia zawodowego jest najwyższy, tj. pośród nauczycieli szkół specjalnych lub placówkach dla młodzieży trudnej.

Na szczególne zastosowanie humoru w praktyce edukacyjnej zwracają uwagę badacze: Eleonore Hofner i Hans-Urlich Schachtner (2012). Polecają oni wykorzystanie stylu prowokatywnego w pracy edukacyjnej i terapeutycznej. Jest to metoda wywierania wpływu poprzez humor i stawianie wyzwań. Ich zdaniem kontrolowane wywoływanie śmiechu i sprzeciwu przynosi bardzo wiele korzyści i dzięki temu łatwiej jest osiągnąć założony cel. „Śmiech uwalnia, a sprzeciw mobilizuje do działania" (s. 27) - dlatego zdaniem autorów żart wymierzony w absurdalność zachowania bądź jego szkodliwość, a nie w drugiego człowieka może sprowokować zmianę w postrzeganiu otaczającej rzeczywistości, a więc zmianę postaw, a nawet zachowania. Dodatkowo autorzy uważają, że umiejętność żartowania z samego siebie wymaga od jednostki posiadania dużej ilości dystansu do siebie samego i otoczenia społecznego. Dla niektórych nauczycieli czy terapeutów styl prowokatywny może wydawać się zbyt agresywny bądź ryzykowny w zastosowaniu. Dlatego autorzy zaznaczają, że warunkiem korzystania $\mathrm{z}$ niego jest poszanowanie godności drugiego człowieka. Zastosowanie tego typu postępowania nie jest niczym nowym i wiele osób stosuje tę taktykę w komunikacji z innymi ludźmi. Intuicyjnie wykorzystują ją także nauczyciele pracujący z dziećmi i młodzieżą w różnym wieku. U podstaw efektywnego zastosowania humoru i prowokacji w procesach wychowania czy nauczania - uczenia się musi leżeć także bardzo dobra znajomość procesów rozwojowych wychowanków, a także ich indywidualnych cech osobniczych. 


\section{CEL BADAŃ I PROBLEMY BADAWCZE}

Dotychczasowe badania wykazały m.in. istotną rolę poczucia humoru w budowaniu relacji międzyludzkich i atmosfery w grupie, budowaniu odporności osób zmagających się ze stresem, przeciwnościami losu i kryzysami życiowymi (Lefcourt 2001; Radomska 2002; Martin i in, 2003; Masten 2007; za: Karłyk-Ćwik 2016). Arnie Cann i Kanako Taku (2010) stwierdzają, że większość badaczy zajmujących się tym zagadnieniem skłania się ku postrzeganiu humoru jako wielowymiarowego zasobu osobistego, który był analizowany najczęściej w kontekście pozytywnego oddziaływania na jednostkę. Zdecydowanie rzadziej humor był badany pod kątem celowości angażowania się jednostek w negatywne jego formy. Dopiero kwestionariusz do badania stylów humoru (Martin i in. 2003) i zaproponowana przez jego twórców koncepcja funkcji stylów humoru skorygowała ten niedostatek, zwracając uwagę na pozytywne, ale też negatywne aspekty i konsekwencje jego wykorzystania.

Humor stanowi integralną część szeroko pojmowanych relacji interpersonalnych. W relacji nauczyciel - uczeń jest nieodzowny, pożądany i pełni różnorodne funkcje. Zastosowanie humoru w codziennej pracy nauczyciela nie tylko wpływa pozytywnie na klimat szkoły, wzajemne relacje, ale także procesy nauczania uczenia się i wychowania. Chroni nauczycieli przed wypaleniem zawodowym, może stanowić także skuteczną strategię terapeutyczną wyrażoną chociażby $\mathrm{w}$ stylu prowokatywnym. Wraz z upływem lat i przemianami cywilizacyjnymi zachodzi potrzeba podjęcia ponownego dialogu na temat efektywnej komunikacji pomiędzy uczniem i nauczycielem (Musiatewicz 2014), dlatego warto się przyjrzeć mało zbadanemu zjawisku w praktyce edukacyjnej, jakim jest humor. W związku z tym, a także na postawie analizy dostępnej literatury i obserwacji własnej praktyki edukacyjnej, celem podjętych badań było zbadanie poziomu stylów humoru prezentowanych przez nauczycieli oraz przyjrzenie się różnicom występujących w zakresie tej grupy badawczej.

Wobec powyższego sformułowano następujące pytania badawcze:

1. Jakie style poczucia humoru prezentują badani nauczyciele?

2. Czy istnieją różnice istotne statystycznie pomiędzy stylami poczucia humoru u nauczycieli edukacji przedszkolnej a nauczycielami uczących w szkołach podstawowych?

3. Czy istnieją różnice istotne statystycznie pomiędzy stylami poczucia humoru nauczycieli uczących w szkołach i przedszkolach miejskich a pracującymi w szkołach, przedszkolach wiejskich?

4. Czy istnieje związek pomiędzy wiekiem i stażem pracy badanych osób a prezentowanymi stylami poczucia humoru? 
W związku z brakiem danych dotychczasowych badań o takim charakterze do ostatniego pytania badawczego, które jest pytaniem o związek, nie została postawiona hipoteza badawcza.

\section{GRUPA BADAWCZA, TEREN I ORGANIZACJA BADAŃ}

Badaniami objęto grupę 41 nauczycieli w wieku 27-63 lata, z czego 21 osób pracuje w szkole podstawowej, a 20 nauczycieli w przedszkolu. Ze względu na to, że w szkołach, a w szczególności przedszkolach, pracują w głównej mierze tylko kobiety w badaniach wzięło udział 35 kobiet i tylko 6 mężczyzn. Badania prowadzone były na terenie miasta Lublin (60,98\% badanych) i sąsiadujących z nim wiosek (39,02\% osób badanych) w okresie maj-czerwiec 2018 roku. Dobór do nich był losowy. Wiek osób badanych był bardzo zróżnicowany i mieścił się w przedziale 27-63 lata, podobnie jak staż pracy w zawodzie nauczyciela, który zamknął się w zakresie 3-32 lata. Badani nauczyciele zatrudnieni są w przedszkolach (20 osób) i szkołach podstawowych (21 osób).

\section{METODA I NARZĘDZIE BADAWCZE}

Badania nad humorem w Polce nie są popularne, a metod jest niewiele. Dotychczas zostało przetłumaczonych i znormalizowanych na próbie polskiej zaledwie kilka narzędzi badawczych. Jednym $\mathrm{z}$ nich jest wykorzystany w przeprowadzonych badaniach samoopisowych Kwestionariusz Stylów Humoru (HSQ) autorstwa Roda Martina, Patrici Puhlik-Doris, Gwena Larsena, Jeanette Gray i Kelly Weir (2003). U podstaw konstrukcji narzędzia leży koncepcja stylów humoru traktowanych w perspektywie różnic indywidualnych. Jej autorzy podkreślają funkcjonalne znacznie humoru dla dobrostanu jednostki. Podstawą do wyróżnienia typów humoru w opracowanych przez nich kwestionariuszu są dwa wymiary: adaptacyjność oraz funkcje interpersonalne i intrapsychiczne w życiu jednostki. Badanie związków pomiędzy dobrostanem a humorem, a także wiedza na temat funkcji, stylu i adaptacyjnych bądź nieadaptacyjnych form poczucia humoru doprowadziła autorów do stworzenia modelu 2 × 2 przedstawionego w tabeli 1 (Hornowska, Charytoniuk 2011). 
Tabela 1. Model stylu poczucia humoru według Roda Martina (za: Hornowska, Charytoniuk 2011)

\begin{tabular}{|c|ccc|}
\cline { 3 - 3 } \multicolumn{2}{c|}{} & \multicolumn{2}{c|}{ Ukierunkowanie } \\
\cline { 2 - 4 } & Adaptacyjny & Interpersonalne & Intrapsychiczne \\
\hline \multirow{3}{*}{$\begin{array}{c}\text { Adaptacyjność } \\
\text { humoru }\end{array}$} & Humor afiliacyjny & $\begin{array}{c}\text { Humor wzmacniający Ja } \\
\text { /Humor w służbie ego }\end{array}$ \\
\cline { 2 - 4 } & Nieadaptacyjny & Humor agresywny & $\begin{array}{c}\text { Humor samoponiżający } \\
\text { /Humor samodeprecjo- } \\
\text { nujacy }\end{array}$ \\
\hline
\end{tabular}

Dwa z przedstawionych typów poczucia humoru, tj. humor afiliacyjny i humor w służbie ego (wzmacniający Ja), są istotne dla dobrego samopoczucia jednostki, natomiast humor deprecjonujący (samoponiżający) i agresywny zostały uznane za nieadaptacyjne i szkodliwe. Według stworzonej przez autorów koncepcji stylów poczucia humoru każdy z nich wykorzystywany jest do innych celów i w różnych sytuacjach:

- humor wzmacniający Ja (w służbie ego) służy do polepszenia samopoczucia osoby, podniesienia jej samooceny, stosowany jest często w sytuacjach stresowych jako mechanizm obronny, w celu rozładowania napięcia; przyczynia się do zmiany perspektywy postrzegania danej sytuacji przez jednostkę;

- humor agresywny - to typ humoru, w którym osoba stosująca go podnosi własny nastrój bądź samoocenę poprzez żartowanie, szydzenie z innych osób;

- humor afiliacyjny stosowany przez jednostkę w celu zbudowania bądź pogłębienia relacji z innymi ludźmi, poprzez rozweselanie innych, opowiadanie żartów, zabawnych historii czy stosowanie riposty;

- humor samoponiżający (samodeprecjonujący) - to humor, który tak jak afiliacyjny służy do nawiązywania relacji z ludźmi, ale poprzez żartowanie $\mathrm{z}$ siebie samego w sposób nadmierny, dyskredytujący własną osobę.

Kwestionariusz Stylów Humoru jest złożony z 32 twierdzeń. Zadaniem respondentów jest odnieść się do nich i określić swoje nastawienie na skali siedmiostopniowej. Na każdy z czterech typów humoru składa się 8 pytań, dlatego możliwy do uzyskania zakres punktowy to 8-56 punktów. Pierwsze próby wykorzystania skali w warunkach polskich zostały podjęte w 2005 roku przez Joannę Strzelczyk (2005), a ostateczna jej wersja została opracowana w 2009 roku przez Joannę Charytoniuk.

\section{PREZENTACJA I DYSKUSJA WYNIKÓW BADAŃ WŁASNYCH}

Teoretyczne rozważania nad znaczeniem humoru w relacjach interpersonalnych i relacjach wychowawczych pokazują, że odgrywa on istotną rolę zarówno w ich 
budowaniu i podtrzymywaniu relacji, jak i rozwiązywaniu sytuacji trudnych czy stresowych, których w pracy nauczyciela nie brakuje. Humor chroni także przed wypaleniem zawodowym i podnosi atrakcyjność zajęć prowadzonych przez nauczycieli.

Wyniki prowadzonych badań własnych w zakresie stylów poczucia humoru prezentowanych przez nauczycieli szkół podstawowych i przedszkoli prezentuje tabela 2.

Tabela 2. Style humoru nauczycieli $(N=41)$

\begin{tabular}{|l|c|c|c|c|c|}
\hline \multicolumn{1}{|c|}{ Style humoru } & $\boldsymbol{M}$ & $\boldsymbol{M e}$ & $\boldsymbol{M i n}$. & Max. & SD \\
\hline Humor afiliacyjny & 37,93 & 38,00 & 26,00 & 49,00 & 6,567 \\
\hline Humor wzmacniający Ja & 35,61 & 34,00 & 16,00 & 50,00 & 6,674 \\
\hline Humor agresywny & 25,63 & 26,00 & 12,00 & 43,00 & 7,880 \\
\hline Humor samoponiżający & 26,54 & 26,00 & 9,00 & 47,00 & 7,527 \\
\hline
\end{tabular}

Okazało się, że styl humoru najczęściej wykorzystywany przez nauczycieli w ich pracy to humor afiliacyjny (HAF 37,93) i humor wzmacniający Ja $(35,61)$. Znacznie rzadziej nauczyciele wykorzystują strategie związane $\mathrm{z}$ humorem agresywnym i samoponiżającym. Oznacza to, że preferowane są przez nich dwie formy humoru określone przez Martina jako adaptacyjne, dzięki którym osoby używające go są w stanie poprawić samopoczucie swoje, a także innych osób z otoczenia. Obydwa typy humoru sprzyjają wytworzeniu pozytywnej atmosfery w środowisku zawodowym nauczycieli i w ich relacjach $\mathrm{z}$ wychowankami. Średnie uzyskane przez nauczycieli w zakresie humoru agresywnego $(25,63)$ i samoponiżającego $(26,54)$ pokazują, że nauczyciele rzadziej czynią siebie i inne osoby podmiotem żartów czy drwin.

Zbliżone wyniki badań otrzymała Anna Karłyk-Ćwik (2016), badając wychowawców ośrodka wychowawczego dla trudnej młodzieży (52 osoby). Dominującym typem humoru był humor afiliacyjny, ze średnią 42,09, następnie humor wzmacniający Ja $(35,37)$. Natomiast typy nieadaptacyjne humoru uzyskały znacznie niższe wskazania średniej, tj. humor agresywny $(22,36)$ i samodeprecjonujący $(26,30)$.

Specyfika pracy nauczyciela zależy od wielu czynników, w tym od wieku uczniów i typu szkoły. Oczywiste jest, że inaczej pracuje się w przedszkolu, w klasach edukacji wczesnoszkolnej, jeszcze inaczej w szkole podstawowej i ponadpodstawowej. Ze względu na wiek rozwojowy dziecka nieco odmienna będzie także postawa i podejście nauczyciela do ucznia, a także styl prezentowanego przez niego humoru. I o ile humor jest pożądaną składową procesów nauczania - uczenia się i wychowania na każdym szczeblu edukacji, o tyle jego rodzaj czy funkcje mogą mieć 
różne proporcje. Dlatego w początkowym etapie badań nad humorem nauczycieli postanowiono sprawdzić, czy istnieje różnica pomiędzy humorem prezentowanym przez nauczycieli przedszkoli a nauczycielami szkół podstawowych (klasy IV-VII). Uzyskane wyniki badań są zaprezentowane w tabeli 3.

Tabela 3. Porównanie stylów humoru nauczycieli pracujących w przedszkolach i szkołach podstawowych

\begin{tabular}{|l|c|c|c|c|c|c|c|}
\hline \multicolumn{1}{|c|}{ Style humoru } & $\begin{array}{c}\boldsymbol{M} \text { przedszkole } \\
\boldsymbol{N}=\mathbf{2 0}\end{array}$ & $\begin{array}{c}\boldsymbol{M} \\
\text { szkoła } \\
\text { podstawowa } \\
\mathbf{N = 2 1}\end{array}$ & $\boldsymbol{t}$ & $\boldsymbol{d} f$ & $\boldsymbol{p}$ & $\begin{array}{c}\boldsymbol{S D} \\
\text { przedszkole }\end{array}$ & $\begin{array}{c}\text { SD } \\
\text { szkoła } \\
\text { podstawowa }\end{array}$ \\
\hline $\begin{array}{l}\text { Humor } \\
\text { afiliacyjny }\end{array}$ & 37,25 & 38,57 & $-0,64$ & 39 & 0,526 & 6,414 & 6,801 \\
\hline $\begin{array}{l}\text { Humor } \\
\text { wzmacniający Ja }\end{array}$ & 34,40 & 36,76 & $-1,14$ & 39 & 0,263 & 6,621 & 6,678 \\
\hline $\begin{array}{l}\text { Humor } \\
\text { agresywny }\end{array}$ & 27,45 & 23,90 & 1,46 & 39 & 0,152 & 6,613 & 8,729 \\
\hline $\begin{array}{l}\text { Humor } \\
\text { samoponiżający }\end{array}$ & 27,90 & 25,24 & 1,14 & 39 & 0,263 & 8,843 & 5,949 \\
\hline
\end{tabular}

Okazuje się, że pomiędzy stylami humoru nauczycieli pracujących z dziećmi w wieku przedszkolnym i nauczycieli uczniów szkół podstawowych nie zachodzą różnice istotne statystycznie. W zakresie humoru afiliacyjnego średnie wyników są zbliżone (przedszkole - 37,25; szkoła podstawowa - 38,57) i świadczą o częstym wykorzystaniu tego stylu w życiu i pracy. Podobnie przedstawiają się wyniki w kategorii humoru wzmacniającego Ja - średnia jest niewiele niższa od tej uzyskanej w zakresie humoru afiliacyjnego, co świadczy o równie częstym jego zastosowaniu (przedszkole - 34,40; szkoła podstawowa - 36,76). Odchylenia standardowe w obydwu przypadkach są podobne i wskazują na zbliżony rozkład uzyskanych wyników w obydwu grupach badawczych. Pomimo braku różnic istotnych statystycznie pomiędzy poziomami humoru afiliacyjnego i wzmacniającego Ja nauczycieli w dwóch omawianych typach placówek nieznacznie wyższe wyniki w adaptacyjnych rodzajach humoru otrzymali nauczyciele szkół podstawowych. Natomiast inaczej przedstawia się sytuacja posługiwania nieadaptacyjnymi formami humoru, tj. humorem agresywnym i samoponiżającym. Okazuje się, że co prawda zarówno nauczyciele szkół podstawowych, jak i przedszkoli zadeklarowali niższy poziom wykorzystania nieadaptacyjnych jego postaci w życiu codziennym, w tym w pracy, ale nauczyciele przedszkoli wykazali się nieznacznie wyższymi średnimi od nauczycieli ze szkół podstawowych. W zakresie humoru agresywnego średnia wyników nauczycieli przedszkoli to 27,45, a nauczycieli szkół podstawowych - 23,92, w zakresie humoru 
samodeprecjonującego zaś nauczyciele przedszkola uzyskali wynik 27,90, a nauczyciele dzieci ze szkół podstawowych - 25,24. Należy stwierdzić, że co prawda różnice pomiędzy obydwoma badanymi grupami nie są istotne statystycznie, ale zauważa się wykazywanie pewnych tendencji stylów poczucia humoru w zależności od typu placówki. Zaskakujące w przeprowadzonych badaniach okazało się, że to właśnie nauczyciele placówek dla najmłodszych dzieci wykazali nieznacznie wyższy poziom humoru agresywnego i samoponiżającego, przy jednocześnie praktycznie takim samym poziomie humoru afiliacyjnego i wzmacniającego. Analiza odchyleń standardowych dla badanych grup pokazuje, że nauczyciele zatrudnieni w przedszkolach i szkołach podstawowych wykazali podobny poziom spójności odpowiedzi ustosunkowując się do wykorzystania afiliacyjnego i wzmacniającego Ja stylu humoru w życiu codziennym. Mniejszy poziom spójności charakteryzuje ich w zakresie nieadaptacyjnych stylów humoru, gdzie w kategorii humoru agresywnego nauczyciele szkół podstawowych wykazali mniejszą jednorodność poglądów, w porównaniu z nauczycielami przedszkolaków, a w obrębie humoru samodeprecjonującego większa spójność wyników wystąpiła w grupie nauczycieli szkół podstawowych.

Nieznacznie wyższy poziom humoru agresywnego i samoponiżającego u nauczycieli przedszkoli skłania do refleksji. Być może jest on związany z tym, że praca $\mathrm{z}$ małymi dziećmi w przedszkolach jest inna od pracy nauczycieli w szkołach podstawowych i zdecydowanie częściej opiera się na wykorzystaniu przez nich w pracy stylu prowokatywnego. Analizując otrzymane wyniki badań, nie można się także oprzeć wrażeniu, że określone jako nieadaptacyjne style humoru, tj. humor samoponiżający i agresywny, nie zawsze pełnią taką funkcje. Pokusić się należy także o stwierdzenie, że samoderpecjonujące spojrzenie na własną osobę, a także umiejętnie stosowane żarty z drugiej osoby, postrzegane są niejednokrotnie w sposób pozytywny. Zależy to oczywiście w dużej mierze zarówno od osoby stosującej takie strategie, sytuacji, osobowości podmiotu żartów, jak i jego otoczenia. Znamienna jest również forma i natężenie wykorzystania tego typu humoru, a także poczucie, że stosując go nie zawsze jest się dobrze rozumianym. I o ile w zakresie adaptacyjnych stylów humoru zagrożenie przekroczeniem granic w relacjach interpersonalnych $\mathrm{w}$ zasadzie nie istnieje, o tyle posługiwanie się nieadaptacyjnymi jego formami jest ryzykowne. Czy zatem humor agresywny i samoponiżający, który prawdopodobnie wiąże się ze stosowaniem przez nauczycieli taktyk prowokatywnych, jest jednoznacznie zły czy dobry? Czy rzeczywiście i do końca jest on nieadaptacyjny, czy jednak zależy to od natężenia i umiejętnego jego wykorzystania? Na to pytanie odpowiedź może przynieść jedynie dalsza eksploracja badawcza. Na braki w tym zakresie wskazuje także Arnie Cann i Kanako Taku (2010).

Przeprowadzone badania własne nie wykazały różnic istotnych statystycznie pomiędzy stylami poczucia humoru prezentowanymi przez nauczycieli pracujących 
w placówkach zlokalizowanych na terenie miast a nauczycielami pracującymi na wsi (tab. 4).

Tabela 4. Porównanie stylów humoru nauczycieli pracujących w szkołach miejskich i wiejskich

\begin{tabular}{|l|c|c|c|c|c|c|c|}
\hline \multicolumn{1}{|c|}{ Style humoru } & $\begin{array}{c}\boldsymbol{M} \\
\text { miasto } \\
\boldsymbol{N = \mathbf { 2 5 }}\end{array}$ & $\begin{array}{c}\boldsymbol{M} \\
\text { wieś } \\
\mathbf{N = 1 6}\end{array}$ & $\boldsymbol{t}$ & $\boldsymbol{d f}$ & $\boldsymbol{p}$ & $\begin{array}{c}\boldsymbol{S D} \\
\text { miasto }\end{array}$ & $\begin{array}{c}\boldsymbol{S D} \\
\text { wieśs }\end{array}$ \\
\hline Humor afiliacyjny & 37,08 & 39,25 & $-1,03$ & 39 & 0,308 & 6,231 & 7,057 \\
\hline Humor wzmacniający Ja & 34,16 & 37,88 & $-1,79$ & 39 & 0,082 & 6,189 & 6,965 \\
\hline Humor agresywny & 25,16 & 26,38 & $-0,48$ & 39 & 0,636 & 6,401 & 9,952 \\
\hline Humor samoponiżający & 25,24 & 28,56 & $-1,39$ & 39 & 0,171 & 7,172 & 7,848 \\
\hline
\end{tabular}

Analiza średnich uzyskanych w obydwu grupach wykazała, że nauczyciele pracujący w szkołach i przedszkolach wiejskich uzyskali średnie wyników nieznacznie wyższe $\mathrm{w}$ każdym $\mathrm{z}$ badanych stylów poczucia humoru. W zakresie humoru afiliacyjnego średnia dla reprezentantów grup wyniosła: miasto - 37,08, wieś - 39,25, a dla humoru wzmacniającego Ja - 34,16, dla nauczycieli uczących w mieście i 37,88 dla nauczycieli pracujących na wsiach. Podobnie jak w adaptacyjnych stylach humoru, tak i w nieadaptacyjnych badani osiągnęli wyższe wyniki: humor agresywny - 25,16 w mieście, 26,38 na wsi; humor samoponiżający - 25,24 w mieście, 28,56 na wsi. Należy także zaznaczyć, że średnie uzyskane przez nauczycieli pracujących na terenach wiejskich w zakresie humoru afiliacyjnego i wzmacniającego należą do najwyższych $\mathrm{w}$ prowadzonym badaniu. Zauważona różnica pomiędzy nauczycielami pracującymi na wsi i w mieście jest nieznaczna, ale jednorodna. Być może wynika ona $\mathrm{z}$ tego, że badania zostały przeprowadzone $\mathrm{w}$ małych szkołach wiejskich, w których pracujący nauczyciele pochodzą z tych samych lokalnych społeczności co uczniowie, co sprzyja większemu poziomowi integracji oraz znajomości uczniów i nauczycieli. Mniejsza liczba mieszkańców, mniejsze szkoły, mniejsze klasy, a nawet mniejsze grono pedagogiczne - to wszystko pozwala na nawiązanie bliższych relacji, w obrębie których łatwiej jest nauczycielom żonglować żartami i różnymi stylami poczucia humoru, bez obawy, że będzie to źle odebrane. Prawdopodobnie nauczyciele pracujący w szkołach wiejskich czują większą swobodę w zakresie posługiwania się w pracy humorem, zarówno w generowaniu, jak i odbieraniu sytuacji komicznych. Analiza wartości odchyleń standardowych w obydwu badanych grupach we wszystkich czterech stylach humoru wykazuje, że nauczyciele pracujący na wsiach wykazali się większą różnorodnością wyników, a wyniki nauczycieli pracujących w mieście są bardziej spójne. 
Analizując związek pomiędzy stylami humoru a wiekiem i stażem pracy osób badanych, stwierdzono, że wraz z upływem lat nauczyciele wykazywali coraz niższy poziom w każdym z badanych stylów poczucia humoru (tab. 5).

Tabela 5. Związek wieku i stażu pracy nauczycieli z prezentowanymi stylami humoru

\begin{tabular}{|l|c|c|}
\hline \multicolumn{1}{|c|}{ Styl humoru } & Wiek & Staż pracy \\
\hline Humor afiliacyjny & $-0,28$ & $-0,27$ \\
\hline Humor wzmacniający Ja & $-0,08$ & $-0,01$ \\
\hline Humor agresywny & $-0,55$ & $-0,42$ \\
\hline Humor samoponiżający & $-0,25$ & $-0,14$ \\
\hline
\end{tabular}

Zależność ta wystąpiła zarówno w przypadku wieku, jak i stażu pracy osób badanych, jednak w większości przypadków jest ona słaba. Najsilniejszy związek odnotowano pomiędzy stylem agresywnym humoru a wiekiem osób badanych $(-0,55)$, a także pomiędzy humorem agresywnym a stażem pracy $(-0,42)$. Zaobserwowana zależność spadku poziomu wszystkich stylów poczucia humoru wraz z wiekiem i stażem pracy nauczycieli może być postrzegana w dwojaki sposób. Z jednej strony naturalne jest, że im starsza osoba, tym jej osobowość, obraz siebie czy poczucie własnej wartości jest bardziej stabilne i spójne, dlatego starsi nauczyciele $z$ wiekiem, doświadczeniem zawodowym, a także stabilizacją zawodową coraz rzadziej stosują strategie związane $\mathrm{z}$ wykorzystaniem poczucia humoru. Nie mają oni także potrzeby angażowania się w działania mające na celu wzmocnienie własnej pozycji zawodowej, poprawy własnego wizerunku, czy „wykorzystywania” siebie lub innych osób dla osiągnięcia założonego celu. Szczególnie istotna jest informacja o spadku poziomu używania stylu agresywnego w kontaktach z innymi ludźmi wraz z wiekiem, a także stażem pracy, która może wynikać z rozwojowych zmian w osobowości starszych nauczycieli lub z bogactwa doświadczenia i świadomości konsekwencji, z jakimi może wiązać się wykorzystanie tego stylu humoru. Wycofywanie się wraz z wiekiem ze strategii używania poczucia humoru w życiu i w pracy może przekładać się także na większe wykorzystanie innych technik, które pozwalają na takie samo, albo nawet lepsze, radzenie sobie z sytuacjami życia codziennego. Powodem tego stanu rzeczy jest także różnica pokoleniowa pomiędzy nauczycielem a uczniami, pogłębiająca się z każdym rokiem życia i pracy nauczyciela.

Z drugiej strony jednak analizując osiągnięty kierunek zależności można zauważyć, że za spadek poziomu humoru nauczycieli wraz z wiekiem i stażem pracy odpowiada pogłębiająca się rutyna, monotonność w postrzeganiu swoich obowiązków, a także pojawiające się wypalenie zawodowe. Nauczyciele, którzy są 
starsi zarówno wiekiem, jak i stażem pracy, nie zawsze angażują się w takim samym stopniu w podejmowane działania, jak na początku swojej pracy zawodowej. Podjęte analizy oraz osiągnięte zależności i tendencje skłaniają ku szerszemu przyjrzeniu się temu zagadnieniu, chociażby w kontekście potrzeby stosowania humoru jako profilaktyki wypalenia zawodowego (Bulzak, Adamczyk, Kordek 2016).

\section{PODSUMOWANIE I WNIOSKI KOŃCOWE}

Przeprowadzone badania własne przyniosły następujące odpowiedzi na postawione pytania badawcze:

1. W odpowiedzi na pierwsze pytanie badawcze dotyczące tego, jakie są style humoru nauczycieli stwierdzono, że nauczyciele najczęściej wykorzystują styl afiliacyjny i wzmacniający Ja, zdecydowanie rzadziej styl agresywny i samoponiżający. Oznacza to, że nauczyciele najczęściej wykorzystują humor $\mathrm{w}$ celu nawiązania lub polepszenia relacji z innymi ludźmi bądź rozładowania napięcia w sytuacji trudnej czy stresowej. Zdecydowanie rzadziej korzystają ze stylu agresywnego skierowanego w drugą osobę i samoponiżającego siebie.

2. Odpowiadając na drugie pytanie badawcze, należy stwierdzić, że pomiędzy nauczycielami zatrudnionymi w przedszkolach a nauczycielami ze szkół podstawowych nie zaszła różnica istotna statystycznie w zakresie prezentowanych stylów poczucia humoru, jednak zauważono pewne tendencje. Poziom humoru samoponiżającego i agresywnego był wyższy pośród nauczycieli z przedszkoli w porównaniu z nauczycielami ze szkół podstawowych, przy jednocześnie takim sam poziomie humoru afiliacyjnego i wzmacniającego Ja. Owa tendencja może być powiązana z częstszym stosowaniem strategii prowokatywnych w pracy z dziećmi albo z innymi czynnikami wynikającymi ze specyfiki pracy z dziećmi młodszymi. Otrzymana inklinacja jest interesująca i powinna być pogłębiona w dalszych eksploracjach badawczych.

3. Trzecie pytanie badawcze dotyczyło różnic istotnych statystycznie pomiędzy stylami poczucia humoru nauczycieli pracujących na wsi i w miastach. Osiągnięte w badaniu wyniki pokazały, że różnice te nie są istotne statystycznie, ale dostrzeżono, że nauczyciele pracujący w szkołach wiejskich osiągnęli nieznacznie wyższy poziom średnich wyników we wszystkich badanych stylach humor. Prawdopodobnie jest to związane $\mathrm{z}$ funkcjonowaniem tej grupy osób badanych w mniejszych społecznościach szkolnych sprzyjającym większej swobodzie w stosowaniu różnych stylów humoru, a także odbieraniu napotkanych sytuacji jako komiczne. 
4. Badanie związku pomiędzy stylami poczucia humoru a wiekiem i stażem pracy wykazało, że wraz z wiekiem nauczyciele coraz mniej chętnie wykorzystują strategie związane z humorem. Kierunek korelacji pomiędzy wiekiem osób badanych i stylami humoru jest ujemny, podobnie jak w przypadku stażu pracy. Siła korelacji pomiędzy stylem afiliacyjnym, wzmacniającym Ja i samoponiżającym a wiekiem i stażem pracy jest słaba. Silna zależność zaszła pomiędzy humorem agresywnym a wiekiem i stażem pracy badanych nauczycieli. Spadek wykorzystywania poczucia humoru wraz z upływem lat może wiązać się z naturalnymi zmianami w osobowości, wykorzystaniem innych technik w osiąganiu własnych celów bądź też bazowaniu na zbudowanym już wizerunku-autorytetecie w pracy i życiu. Może łączyć się to także z wypaleniem zawodowym, którego doświadczają nauczyciele pracujący przez wiele lat.

Przeprowadzone badania własne przedstawione w niniejszym opracowaniu są przeprowadzone na zbyt małej liczbie osób i nie można na ich podstawie wyciągnąć wielu pewnych wniosków. Jednakże zauważone tendencje i zależności są zgodne z dostępnymi w literaturze przedmiotu analizami dotyczącymi znaczenia poczucia humoru w życiu codziennym i pracy człowieka. Badania należy powtórzyć na większej grupie nauczycieli pracujących w różnych środowiskach, a także różnych typach placówek oświatowych i wychowawczych. Z uwagi na wnioski innych badaczy, m.in. o tym, że humor chroni przez wypaleniem zawodowym, w szczególności jest to zasadne w przypadku osób pracujących z młodzieżą o specjalnych potrzebach edukacyjnych (Bulzak, Adamczyk, Kordek 2016). Warto także bliżej przyjrzeć się stylom humoru określanym jako nieadaptacyjne, a także ich wpływowi na różne sfery funkcjonowania człowieka, gdyż jak wykazały badania własne, a także wnioski innych autorów, negatywne oddziaływanie humoru jest jak dotąd mało poznane i prawdopodobnie niedoceniane (Cann, Taku 2010).

\section{ZAKOŃCZENIE}

Poczucie humoru nauczycieli, ich otwartość, komunikatywność, umiejętność przekazywania wiedzy to najczęściej pożądane przez uczniów cechy dobrego nauczyciela. Przykro słyszeć opinie uczniów, którzy twierdzą, że nauczycielom na ogół brakuje poczucia humoru i dystansu do samych siebie. W obecnej rzeczywistości szkolnej, gdzie zarówno nauczyciel, jak i uczniowie zmagają się z ogromem problemów, m.in. dewaluacją wartości, upadkiem autorytetów, problemami organizacyjnymi, humor może okazać się pomocny w wielu sytuacjach trudnych. W jaki sposób więc możemy odnieść uzyskane wyniki badań i przedstawione rozważania do praktyki 
edukacyjnej? Odpowiedzią niech będzie wypowiedź Dariusza Chętkowskiego zamieszczona na prowadzonym przez niego Belferblogu - pisarza, publicysty, a przede wszystkim nauczyciela: „Rusza kolejny rok akademicki. Mnie najbardziej interesuje program studiów pedagogicznych. Wydaje mi się, że warto byłoby zatrudnić na polonistyce clowna, aby nauczył studentów poczucia humoru. Mnie w każdym razie brakowało tego przedmiotu. Ponieważ nie zostałem właściwie przygotowany do zawodu, zdarza mi się prowadzić lekcje, jakbym kij połknął. Zdarza mi się też brać zachowanie uczniów za bardzo na poważnie. No cóż, proszę wszystkich młodych ludzi o wybaczenie. Niech usprawiedliwia mnie fakt, że na polonistyce nie zatrudniano clownów. A nie każdy nauczyciel ma poczucie humoru ot tak $\mathrm{z}$ urodzenia. Ja na przykład nie mam. Dlatego zastanawiam się, jak się tego uczyć”.

Postęp cywilizacyjny wymusza zmiany w sferze edukacji. Być może właśnie nadszedł czas, aby definitywnie rozprawić się z wizerunkiem poważnego, wszechwiedzącego nauczyciela i zmienić go na obraz osoby, która ma swoje zalety i wady, a jako priorytet w swojej pracy stawia rozwój ucznia i własny. Przedstawione w niniejszym artykule rozważania prowadzą do konkluzji: humor nauczycieli należy traktować śmiertelnie poważnie.

\section{LITERATURA}

Bulzak A., Adamczyk M., Kordek M., 2016, Wzajemne relacje pomiędzy poczuciem humoru, stresem i wypaleniem zawodowym na przykładzie badań $w$ grupie nauczycieli. „Zeszyty Naukowe Wyższej Szkoły Humanitas. Pedagogika”, 13, 209-223 Cann A., Taku K., 2010, Humor Styles, Positive Personality and Health. „Europe's Journal of Psychology", 6(3), 213-235

Carroll N., 2018, Humor. Wydawnictwo Uniwersytetu Łódzkiego.

Höfner E., Schachtner H.U., 2012, Uzdrawiająca siła uśmiechu. Humor i prowokacja $w$ terapii. Łódź, Wyd. Studio Astropsychologii.

Hornowska E., Charytoniuk J., 2011, Polska adaptacja Kwestionariusza Stylów Humoru (HSQ) R. Martina, P. Puhlik-Doris, G. Larsena, J. Gray i K. Weir. „Studia Psychologiczne", t. 49, z. 4, 5-22.

Karłyk-Ćwik A., 2016, Style humoru wychowanków i wychowawców a klimat społeczny placówek resocjalizacyjnych dla nieletnich. „Resocjalizacja Polska”, 12, 173-194.

Kmita M., 2013, Humour and its Place in the Teacher Training. W: K. Łapot-Dzierwa (red.), A Teacher in the Contemporary Multicultural World. Kraków, Wydawnictwo Uniwersytetu Pedagogicznego.

Machlev M., Karlin N.J., 2016, Understanding the Relationship Between Different Types of Instructional Humor and Student Learning. „Sage Journals”, 1-9. 
Martin A.R., 2003, Sense of humor. W: S.J. Lopez \& C.R. Snyder (red.), Positive Psychology Assessment. A handbook of models and measures. Washington.

Martin R.A., 2007, The Psychology of humor: an integrative approach. San Diego: Elsevier Academic Press.

Martin R.A., Puhlik-Doris P., Lersen G., Gray. J., Weir K., 2003, Individual differences in uses of humor and their relation to psychological well-being: Development of the Humor Styles Ques-tionnaire. „Journal of Research in Personality”, 37, 48-75

Musiatewicz M., 2014, Rola humoru $w$ dialogu między uczniem a nauczycielem. W: E. Dunaj, I. Morawska, M. Latoch-Zielińska (red.), Humor w kulturze i edukacji. Lublin, Wydawnictwo UMCS, 249-263.

Radomska A., 2002, Rola poczucia humoru w proce-sie radzenia sobie ze stresem przegląd badań. W: I. Heszen-Niejodek, J. Matusiak (red.). Konteksty stresu psychologicznego. Katowice: Wydawnictwo Uniwersytetu Śląskiego, 150-166.

Rusek A., 2012, Wielowymiarowość humoru. „Innowacje Psychologiczne”, t. 1, nr 1,, 117-127

Tomczuk-Wasilewska J., 2009, Psychologia humoru. Lublin: Wydawnictwo KUL.

Tomczuk-Wasilewska J., 2010, Przegląd narzędzi do poczucia humoru. „Roczniki Psychologiczne”, t. XIII, nr 2, Wyd. KUL, Lublin, 73-100.

Źródła internetowe:

Chętkowski D., Blogbelfer, opublikowano: https://chetkowski.blog.polityka.pl/2007/09/28/ nauczyciel-nie-smutas/ [dostęp: 3.06.2019].

Słownik języka polskiego PWN, opublikowano: https://sjp.pwn.pl/ [dostęp: 3.06.2019].

\section{STYLES OF TEACHERS HUMOR}

Summary: A humor is a new issue in pedagogy and recently it has been a subject of more advanced scientific research. The article presents the results of the empirical research, whose purpose was to diagnose teachers humor styles. The research sample, testing by the Humor Styles Questionnaire, was a group of 41 primary school teachers and kindergarten teachers. A survey revealed that teachers presented predominantly adaptive humor styles, definitely less often - non-adaptive. It was also noticed that humor styles level decrease along with the age and seniority.

Keywords: humor, humor in education, styles of humor, teachers' humor styles 